\title{
Role of Advertisement Expenses on Fmcg Sector: Case Study of Hindustan Unilever Limited
}

\author{
Ms Rachana Kejriwal, Dr.Dipti Kumar Chakravorty \\ (Assistant Professor and Head of the Department, Department of Commerce, J.D.Birla Institute, Jadavpur \\ University, Kolkata.) \\ (Professor, Department of Commerce, Department of Commerce, University of Calcutta,kolkata)
}

\begin{abstract}
The purpose of present study has been conducted to investigate the role of advertisement on consumer. This paper aims to explore the role of advertisement expenses by the company which leads to increase the sale of the company and the profit of the company which in turn increases the overall growth of the company. This study is done to see the relevance of research and development expenses, advertisement and promotion expenses on the sales and growth of the Company. Annual reports of the Company have been analyzed to evaluate the impact of advertisement expenses. The results exposed that advertisement attracts towards the preference and choices to influence the consumer buying behavior and ultimately leads the sales of the company to grow. Advertisement expenses influences the consumers and increases the sales of the company.
\end{abstract}

Keywords: Advertisement Expenses, FMCG Company, Impact of advertisement on sales, Research and Development expenses.

\section{Introduction}

Advertising has also become an institution of persuasion to promote such social and economic values as safety, health, education benevolence, Liberty, democracy, free enterprise and tolerance. Today, advertising is wide- spread all over the world in different countries. But advertising trends vary from country to country. The turbulent environment of the 20th century, with rapid changes in technology, products, processes, methods cut throat competition and emergence of new marketing challenges only indicates the significant role of advertising, which is expected to play in the survival and growth of business units. Over a century ago, [1]Harper's Weekly commented that advertisements were "a true mirror of life, a sort of fossil history from which the future chronicler, if all other historical monuments were to be lost, might fully and graphically rewrite the history of our time." Advertising is simply an economic movement with only one objective behind to increase the consumer demand of the product as well as to enhance the sales volumes. Many advertisers and agencies believe that advertising creates "magic in the market place" [2] (Russell \& Lane, 1996). Advertising helps in persuading a target market to purchase or to consume a particular brand. It serves to communicate an idea to a large number of people.

\section{Review Of Literature}

Advertising can be defined as "any non-personal presentation and promotion of ideas, goods or services by an identified sponsor"[3] (Keller, Apéria and Georgson, 2008, p.230). It is usually communicated through various media channels, such as television, radio, newspapers, magazines, internet or billboards, and it intends to persuade potential customers to purchase a certain product or service. According to [4] Phillip Kotler (2003), advertising is the most popular marketing communication tools because it is widely used in all business sectors. Terry Flew (2002), defined advertising as: "The way in which the mass media in all of their forms affect the way the audiences act and behave in their daily lives. The forms of media include television, films, songs and other similar forms."'(Flew 2002, p. 12).Advertising has been perceived from divergent viewpoints, some of which are positive and others negative. Wright, Winter and Zeigler (1982) (cited in Akpan, 1996: 157) describe advertising as "ubiquitous ... brash ... pervasive ... materialistic ... dynamic ... annoying ... indispensable ... fascinating ..." This view provides a somewhat balanced appraisal of advertising, with both positive and negative attributes.[5] Ogilvy (2005) notes that "the trouble with most advertising is that it insults the intelligence of the public and bores you to death", while Crystal (1994: 35) says "... advertising has pernicious effect on individuals, social groups and whole societies". From a positive perspective, Winston Churchill (cited in Dunn and Barban, 1986: 11) said 'advertising nourishes the consuming power of men. It sets up before a man the goal of better home, better clothing, better food for himself and his family. It spurs the individual exertion and greater production."Under the concept developed by Kotler, key advertising instruments consists of both print and media adverts, such as print and broadcast adverts, audiovisual material, package-outer, brochures and booklets, billboards, display signs, symbols and logos, motion pictures, posters and leaflets, videotapes and 
reprint of adverts. However, in the recent years, a rapid development of technology has implications on the growth of media and advertising (Grips, 2002).

There are two broad strands in the existing literature on advertising. One looks at advertising as an instrument that provides valuable information to consumers, enabling them to make rational choices by reducing search costs. Another view of advertising is that it persuades consumers by creating unnecessary differentiation among products, which at times may not be real. Thus, it also reduces product competition and creates a serious hindrance to the entry of new firms. [6]H. W. Hepner (in his book Modern Advertising)-He aptly points out "Advertising stimulates competition. It often enables the small businessman to compete with large concerns as well as to start new business."Nothing except the mint can make money without Advertising. Mass production and Mass distribution totally depend on all forms of Advertising. According to Sherlekar[7] -In India Marketers in the near future will have to acknowledge duly the widened role of marketing viz the creator and deliverer of better standard of living to our population. Today marketers are still revolving around production -oriented and sales-oriented older concepts of marketing and give only lip sympathy to consumer oriented, new Marketing concept. [8]Frank Jefkins (in his book Advertising made Simple)- The combination of Advertising and Marketing, that is making things that can satisfy customers, has consistently expanded choice and raised standard of living. According to him the customers are wheels of industry, which have to be, kept turning, and Advertising is the lubricant. Advertising needs no apologist. It is as essential to industrial society as Oxygen is to Human Beings. We cannot buy what we know does not exists. We are capable of forgetting of what is not told to us over and over again. It is worth considering a statement made by Professor John Howard, a lecturer who was appointed by the US Government to analyze testimony given at Federal Trade Commission hearings on American advertising, and quoted in campaign $\left(7^{\text {th }} \mathrm{Jan}, 1972\right)$.He said: "There is a great difference between what the advertising Industry calls persuasion and what many people see as manipulation, confusion and exploitation of the consumer.

In India fast moving consumer goods (FMCG) category has witnessed an outburst of sales promotion activities in the post-liberalization era. In the U.S. context several aspects of consumer perceptions of deal frequency and deal prices have been studied (Aradhna Krishna, Imran S. Curriuun and Robert W. Shoemaker 1991). Whereas Page Moreau, Aradhana Krishna, Bari Harlam (2001) studied differing perceptions with respect to price promotion from the point of manufacturers, retailer and consumers. Effects of promotions on variety seeking and reinforcement behaviour have also been studied. (Barbara Khan and Jagmohan Raju 1991). Advertising's effectiveness lies in its capability to help stimulate or maintain sales [9](Eachambadi 1994; Mantrala, Sinha, and Zoltners 1992; Naik, Mantrala, and Sawyer Sethi 1998; Vidale and Wolfe 1957). Thus, advertising is frequently used as an independent variable in explaining changes in sales (Lilien 1994).

As a promotional strategy, advertising provides a major tool in creating product awareness and condition the mind of a potential consumer to take final purchase decision. As advertiser's primary mission is to reach potential customers and influence their awareness, attitudes and buying behavior[10] (Ayanwale et al., 2005 and Adelaar et al., 2003). Ayanwale et al (2005) conducted research on advertisement of Bournvita, he found as advertising has a major influence on consumers' likeness for Bournvita food drink.

Large Indian companies allocate huge amounts of money for their advertising budgets. Expenditures are always incurred in anticipation of benefits.( International Research Journal of Finance and Economics Issue 42 (2010) 97 ) Thus, advertising expenditure is justifiable only if the benefits derived out of the advertisements are more than the amount incurred in advertising expenditure. It was Chamberlin (1933) who first attempted to integrate advertising with economic theory. Chamberlin's model considered advertising expenditure as a selling cost, its main objective being to shift the demand curve for the firm's differentiated product to the right. Chamberlin accepted that advertising may be informative as it may provide information to consumers or it may be persuasive such that it may alter consumer wants. The objective of informative advertising is to provide information about prices and product features to consumers which make them react more sharply even to small price differences and in this way informative advertising may lead to an increase in the product's price elasticity of demand. The informative view of advertising was further developed by Ozga (1960), Stigler (1961), Telser (1964), Nelson (1970, 1974, 1975) and Demsetz (1973).

\section{Importance Of The Study}

Advertising is about striking the right note on those chords of the brain that most often are in sync with the heart. When this happens, a need is generated and brain directs to buy, be it a product or a service or an idea. Indian advertising too follows this rule but here age-old advertising trends are still thriving along with the latest innovative trends. According to American Marketing Association "Advertising is any paid form, non-personal presentation of ideas, products and services by an identified sponsor." According to J.J. Burnett "Advertising is the non-personal communication of marketing related information to a target audience, usually paid for by the advertiser and delivered through mass media in order to achieve the specific objectives of the sponsor." 
In fact the seeming growth of many advertising industries is instructive of the fact that, complex and uncertain business environment has lead many organizations to device multifaceted approaches to market their products and services through various techniques of advertisements. Moreover, the essence of being in business by any business outfits is to produce for sales and make good profits. Therefore, the hallmarks of remaining in business as a profit oriented organization is to generate enough sales from its product or services not only to cover operating cost but also to sustain the future of the organization. Indeed, for many organizations, sales estimates are the starting point in budgeting or profit planning (Ayanwale, Alimi, and Ayanbimipe, 2005).Despite moderate global growth in advertising spending, fast-moving consumer goods (FMCG) companies continued to invest - and invest more - according to Nielsen's quarterly Global AdView Pulse report shown in figure-1. The largest sector by ad spend market share, with roughly a quarter of all dollars spent (25.1\%), FMCG saw a six percent increase in ad spend in 2012 through September. FMCG was joined by telecom, media and automotive as the top sectors for year-over-year ad growth. Media is the vehicle that is used for the delivery of the message. Some important tools of advertisement are newspapers, magazines, radio, television, direct mail and mail order, outdoor display and transportation[11] (Wells, Burnett \&Moriarty, 2000).

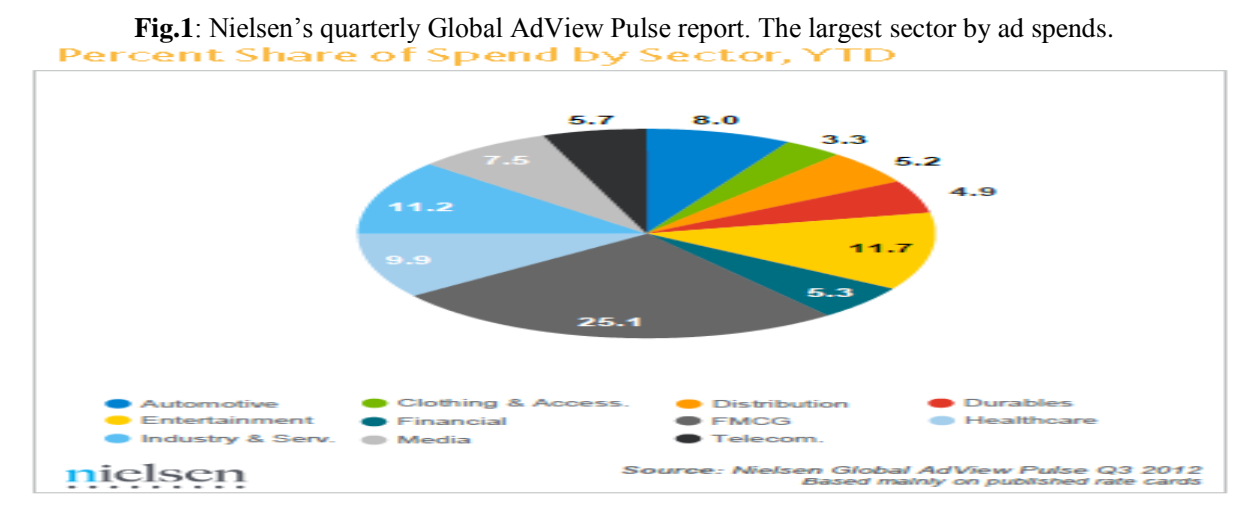

\section{Statement Of The Problem}

It is a matter of fact that all the companies spend a lot of money on advertisements to establish the product in market. It is also important for the companies to know whether their advertisements are effective or not. This study was conducted to find out the impact of advertisement on consumers buying behavior with reference to fast moving consumer goods (FMCG's) everywhere advertisement is involved in our daily life through on television, radio, newspaper, magazine and billboards are common through which advertisement reach us. The Companies are trying to increase their Advertisement expenses to increase the growth of the company affecting the overall sales of the company's growth and increase in the profit. The study is relating to promotion of business organization in FMCG sector in India. It covers the advertising as tool of promotion. Through the help of case study of Hindustan Unilever Limited Company it will be shown that advertisement expenses are very important to increase the overall growth of the FMCG sector of the companies. In brief, promotion, advertising, research and development expenses play a major role in increasing sales in leading companies.

This present study helps in exploring the impact of advertisement expenses of the companies. It is understood that advertisement compared to other sector is more effective in FMCG sector.

\section{Objective Of The Study}

1. To study the impact of the advertisements expenses on consumer behavior.

2. To find out the preference regarding the most important category of FMCG sector.

3. To explore the impact of Advertisement expenses on sales and overall growth of the company.

\section{Hypothesis Formulation}

It is basically a presumption which Researcher uses when they do research.

For objective one:

Null: - There is a no significant effect of the Advertisement s expenses on increase of Sales of the Company.

Alternative: - There is significant effect of the Advertisements expenses on increase of Sales of the Company.

\section{Research Methodology}

The main purpose of the present study is "To know the Role of Advertisement expenses on the overall growth of the company" on FMCG products. Data Collection: data was collected through secondary sources. 
7.1 SECONDARY DATA: Source of secondary data was collected with help of published reports, magazines, and the websites. Annual reports of Hindustan Unilever Limited Company for last 10 years are referred.

7.2 DATA INTERPETATION TOOLS

The most often tools used to Examine are SPSS

- Percentage.

- Pie Charts.

- ANOVAs test.

- Multiple Regression

\section{Results And Discussions}

Hindustan Unilever Limited (HUL) is India's largest Fast Moving Consumer Goods Company with a heritage of over 75 years in India and touches the lives of two out of three Indians.HUL works to create a better future every day and helps people feel good, look good and get more out of life with brands and services that are good for them and good for others. With over 35 brands spanning 20 distinct categories such as soaps, detergents, shampoos, skin care, toothpastes, deodorants, cosmetics, tea, coffee, packaged foods, ice cream, and water purifiers, the Company is a part of the everyday life of millions of consumers across India. Return on marketing investments (ROMI) is an area where the company has stepped up focus in recent times. ROMI is about maximizing the effectiveness of advertising, promotional and trade investments. The efficiencies generated from the above initiatives are ploughed back into enhancing our product offerings. Company continues to drive supply chain to deliver top-quality products with world class service, at a competitive cost. Company is deploying various techniques that allow them to assess all the marketing levers to drive growth and superior yields from marketing investment. The learning's from the past investments are being deployed to improve the effectiveness of future activities. All marketing costs and assumptions are evaluated and savings are derived by stopping non-productive activities or driving better efficiencies on the planned spends.

\section{Advertisement Analysis}

- USP or the common thread through all the advertisements is the Presence of Movie Stars through the ages.

- The product has been positioned on the basis of REFERANCE GROUP by using a celebrity popular at that point in time.

- Some amount of attribute positioning by mentioning the various ingredients has also been done

\section{Findings}

Table 1: Data_collected from the annual reports of Hindustan Unilever Limited Company for the last 10 years.

\begin{tabular}{|c|c|c|c|c|c|c|c|c|c|c|c|}
\hline Year & $\begin{array}{c}\text { Shareho } \\
\text { Iders } \\
\text { Fund }\end{array}$ & $\begin{array}{c}\text { Equity } \\
\text { Shares }\end{array}$ & $\begin{array}{c}\text { Reserve } \\
\text { \& } \\
\text { Surplus }\end{array}$ & $\begin{array}{c}\text { Loan } \\
\text { Funds }\end{array}$ & $\begin{array}{c}\text { Capital } \\
\text { Employe } \\
\text { d }\end{array}$ & $\begin{array}{c}\text { Gross } \\
\text { Sales }\end{array}$ & Net Sales & $\begin{array}{c}\text { Advertis } \\
\text { ing And } \\
\text { Sales } \\
\text { Promoti } \\
\text { on }\end{array}$ & $\begin{array}{c}\text { Researc } \\
\text { h And } \\
\text { Develo } \\
\text { pment }\end{array}$ & $\begin{array}{c}\text { Net } \\
\text { Profit }\end{array}$ \\
\hline \multicolumn{7}{|c|}{ Rupees in Crores } \\
\hline 2003 & 2138.73 & 220.12 & 1918.60 & 1704.3 & 3843.03 & 11096.02 & 10138.35 & 759.09 & 31.20 & 1804.34 \\
\hline 2004 & 2092.71 & 220.12 & 1872.59 & 1471.11 & 3563.82 & 10888.38 & 9926.95 & 835.98 & 36.34 & 1199.28 \\
\hline 2005 & 2305.63 & 220.12 & 2085.50 & 56.94 & 2362.57 & 11365.33 & 11060.55 & 1005.67 & 49.35 & 1354.51 \\
\hline 2006 & 2723.48 & 220.68 & 2502.81 & 72.6 & 2796.08 & 12457.90 & 12103.39 & 1272.88 & 35.74 & 1539.67 \\
\hline 2007 & 1439.23 & 217.75 & 1221.49 & 88.53 & 1527.76 & 14180.43 & 13717.75 & 1422.90 & 49.39 & 1743.12 \\
\hline $\begin{array}{c}15 \\
\text { months }\end{array}$ & & & & & & & & & & \\
\hline $\begin{array}{c}2007- \\
2009\end{array}$ & 2061.51 & 217.99 & 1843.52 & 421.94 & 2483.45 & 20239.33 & 20807.12 & 2130.92 & 74.47 & 2500.71 \\
\hline $\begin{array}{c}2009- \\
2010\end{array}$ & 2583.52 & 218.17 & 2365.35 & 0 & 2583.52 & 17523.80 & 17873.44 & 2391.43 & 81.08 & 2102.68 \\
\hline $\begin{array}{c}2010- \\
2011\end{array}$ & 2633.92 & 215.95 & 2417.97 & 0 & 2633.92 & 19401.11 & 19987.15 & 2764.23 & 93.57 & 2153.25 \\
\hline $\begin{array}{c}2011- \\
2012\end{array}$ & 3512.93 & 216.15 & 3296.78 & 0 & 3512.93 & 23181.09 & 22116.37 & 2634.79 & 155.39 & 2599.23 \\
\hline
\end{tabular}

Table 2: Relevant Ratios from Annual Reports of Hindustan Unilever Limited Company

\begin{tabular}{|c|c|}
\hline Year & Sales/Capital Employed Ratio \\
\hline 2003 & 2.89 \\
\hline 2004 & 3.06 \\
\hline 2005 & 4.81 \\
\hline 2006 & 4.46 \\
\hline
\end{tabular}




\begin{tabular}{|c|c|}
\hline 2007 & 9.28 \\
\hline 15 months 2007-2009 & 8.15 \\
\hline $2009-2010$ & 6.78 \\
\hline $2010-2011$ & 7.37 \\
\hline $2011-2012$ & 6.60 \\
\hline
\end{tabular}

Fig.2: Graph showing growth of Net sales of Hindustan Unilever Limited Company during Study period.

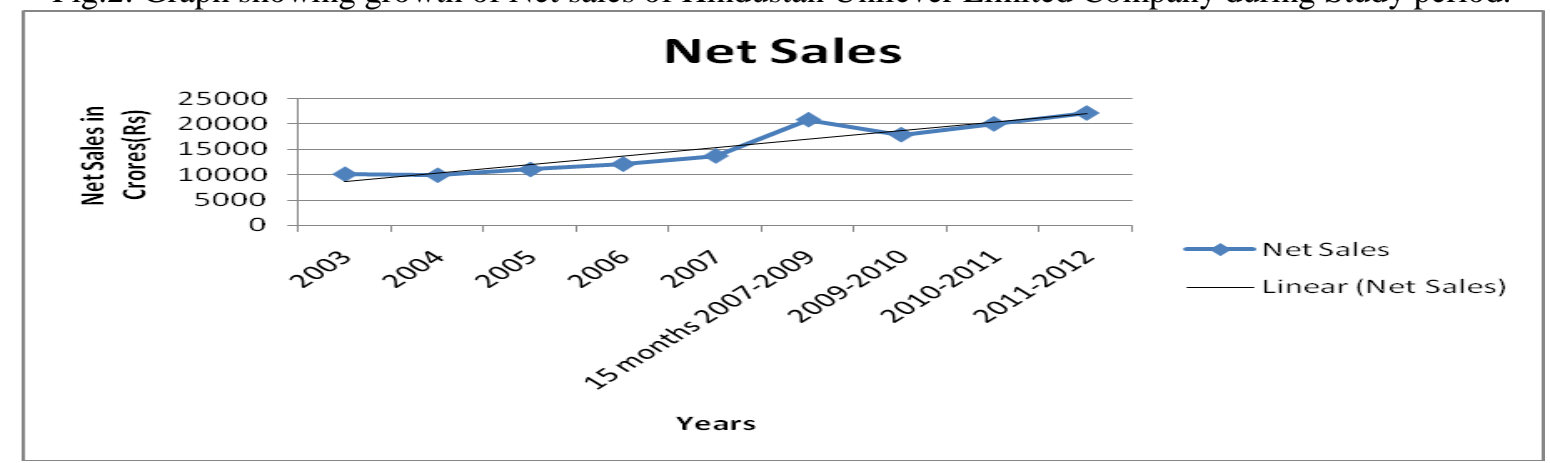

Fig.3:Graph showing the advertisement and Sales Promotion expenses of Hindustan Unilever Limited Company

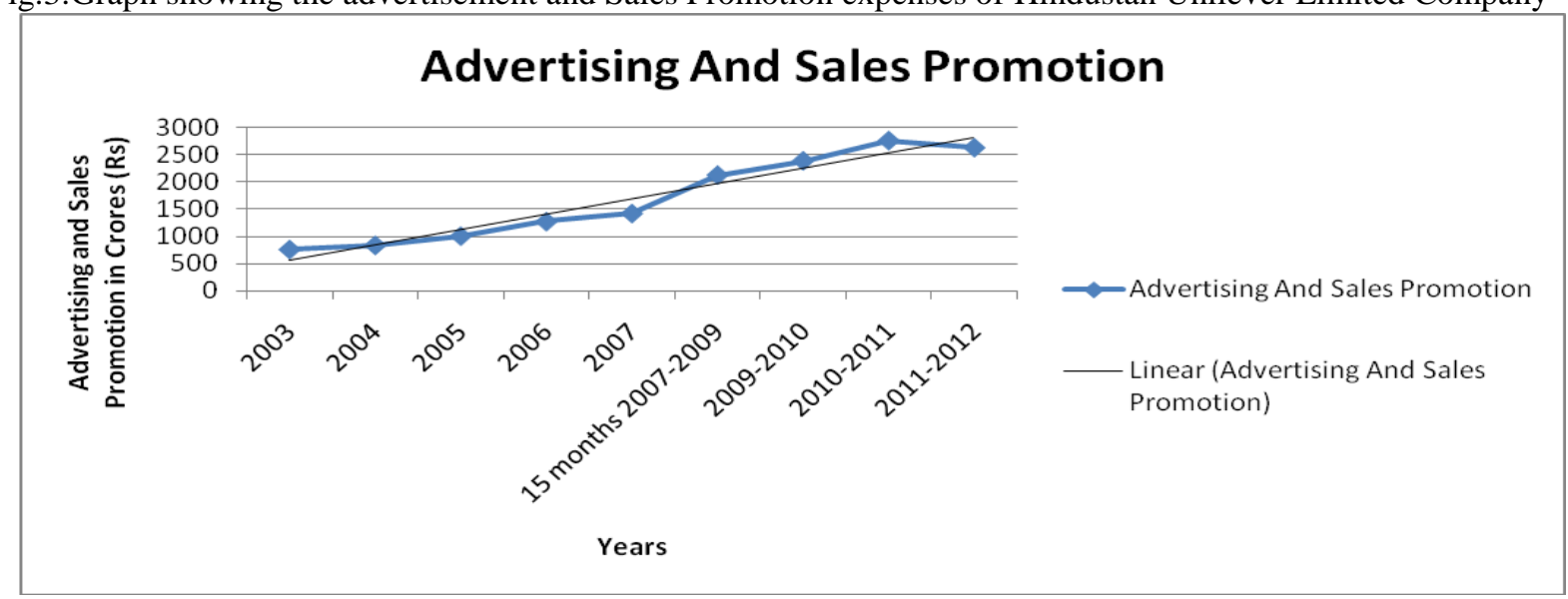

Fig -4: Graph showing the increase of the linear trend ratio of sales/Capital Employed of Hindustan Unilever Limited Company.

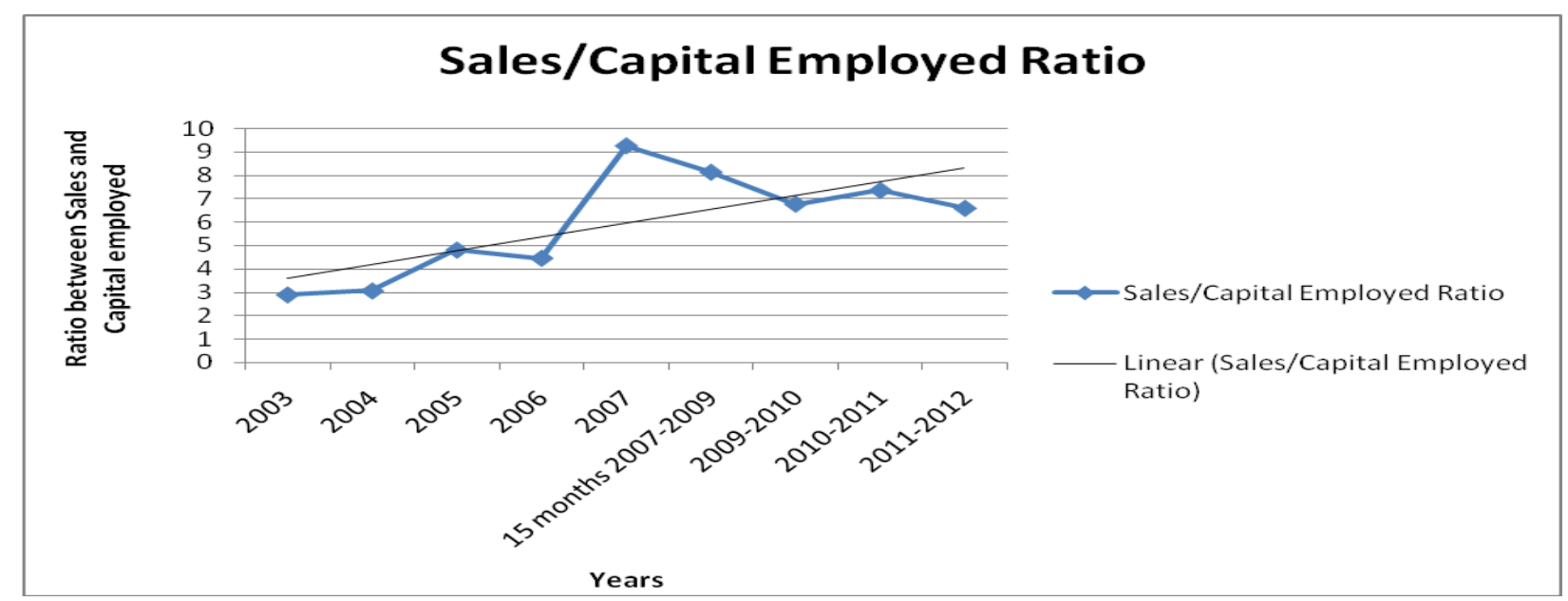

Fig 5:Graph showing the growth of Profit Margin of Hindustan Unilever Limited Company during the Study period. 


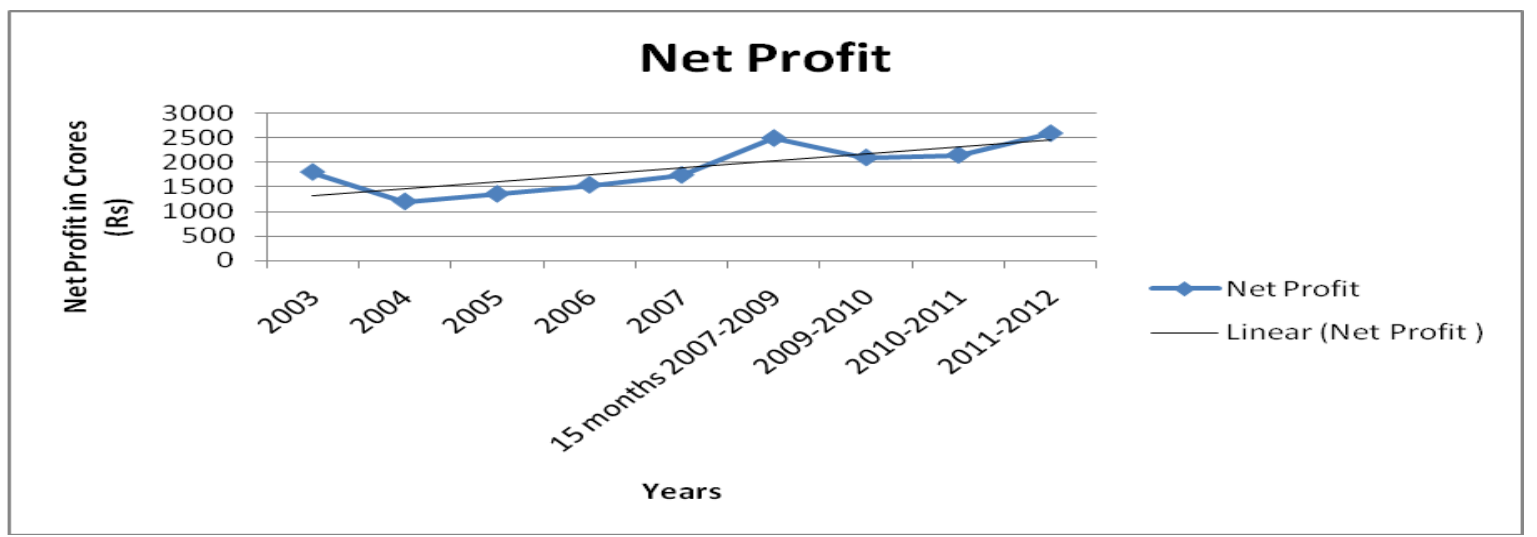

Fig 6:Graph showing the growth of Research and Development expenses of Hindustan Unilever Limited Company during the Study period

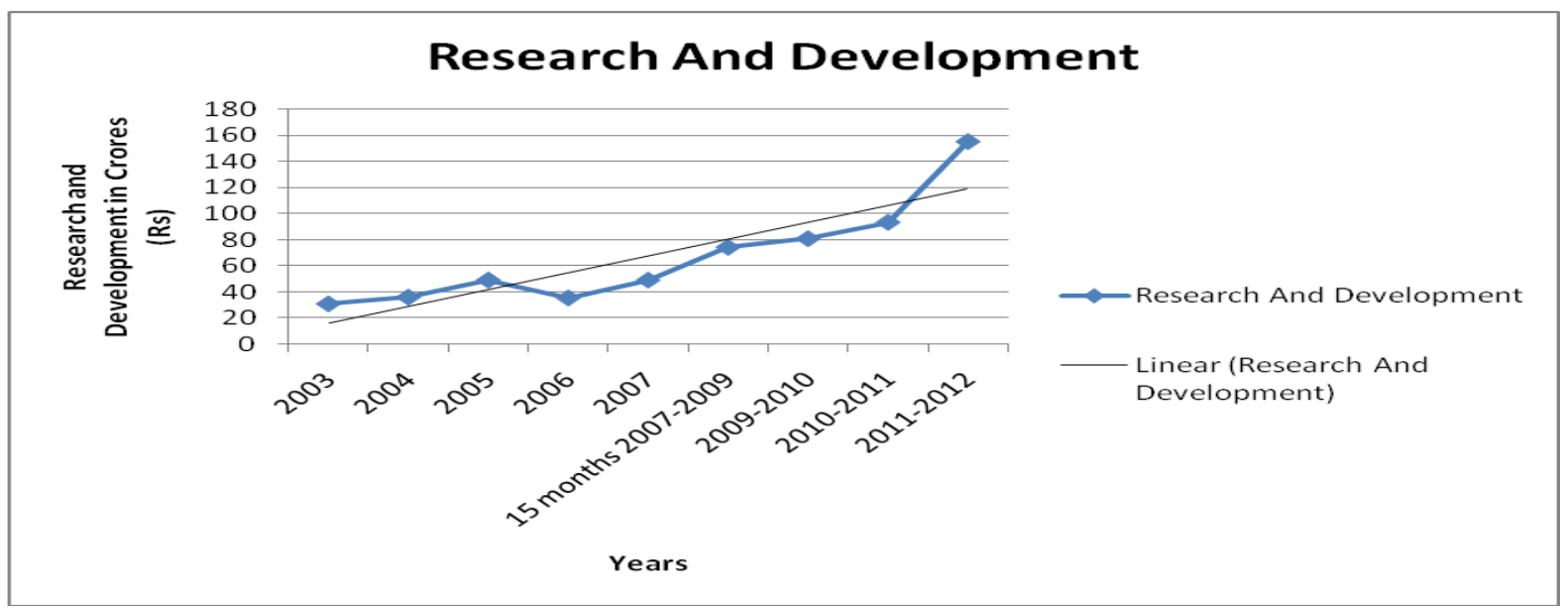

Table 3: Model Expressing the percentage of the dependent and Independent variables

\begin{tabular}{|c|c|c|c|c|c|}
\hline \multicolumn{5}{|c|}{ Model Summary } \\
\hline Company & & $\mathrm{R}$ & R Square & $\begin{array}{c}\text { Adjusted R } \\
\text { Square }\end{array}$ & $\begin{array}{c}\text { Std. Error of } \\
\text { the Estimate }\end{array}$ \\
\hline HUL & & $0.964^{\mathrm{a}}$ & 0.93 & 0.888 & 1538.572 \\
\hline a. Predictors: (Constant), Advertisement expenses., Capital Employed, Research and Promotional Expenses \\
\hline
\end{tabular}

Table 4: Anova table showing the significance level of the dependent variable with the help of $F$ test.

\begin{tabular}{|c|c|c|c|c|c|c|}
\hline \multicolumn{7}{|c|}{ ANOVA } \\
\hline Company & & $\begin{array}{l}\text { Sum of } \\
\text { Squares }\end{array}$ & Df & Mean Square & $\mathrm{F}$ & Sig. \\
\hline \multirow[b]{3}{*}{ HUL } & Regression & $1.58 \mathrm{E}+08$ & 3 & 52540000 & 22.194 & $0.003^{2}$ \\
\hline & Residual & 11840000 & 5 & 2367205 & & \\
\hline & Total & $1.7 \mathrm{E}+08$ & 8 & & & \\
\hline \multicolumn{7}{|c|}{ a. Predictors: (Constant), Advertisement expenses., Capital Employed, , Research and Promotional Expenses } \\
\hline \multicolumn{7}{|c|}{ c. Dependent Variable: Gross Sales } \\
\hline
\end{tabular}

Table 5: Table showing the significance level of the dependent variable with the help of Multiple Regression analysis i.e. T test

\begin{tabular}{|c|c|c|c|c|c|c|}
\hline \multicolumn{7}{|c|}{ Coefficients } \\
\hline \multirow[b]{2}{*}{ Company } & & \multicolumn{2}{|c|}{ Unstandardized Coefficients } & \multirow{2}{*}{$\begin{array}{c}\begin{array}{c}\text { Standardized } \\
\text { Coefficients }\end{array} \\
\text { Beta }\end{array}$} & \multirow[b]{2}{*}{$\mathrm{T}$} & \multirow{2}{*}{$\begin{array}{c}\mathrm{P}- \\
\text { Value(Sig } \\
\text { ) }\end{array}$} \\
\hline & & $\mathrm{B}$ & Std. Error & & & \\
\hline \multirow{4}{*}{ HUL } & (Constant) & 6827.519 & 3012.013 & & 20.267 & 0.073 \\
\hline & Capital Employed & -0.069 & 0.868 & -0.011 & -0.079 & 0.94 \\
\hline & $\begin{array}{c}\text { Research and } \\
\text { Promotional Expenses }\end{array}$ & 49.839 & 29.645 & 0.43 & 10.681 & 0.154 \\
\hline & Advertisement Expenses & 3.312 & 1.496 & 0.571 & 20.214 & 0.078 \\
\hline & : Gross Sales & & & & & \\
\hline
\end{tabular}


Summary of findings of Hindustan Unilever Limited

Table 1 represents the relevant figures of Hindustan Unilever Limited about the Shareholders funds, Equity Shares of the Company, Reserve and surplus, Loan funds, Capital employed ,Gross sales, Net sales ,Advertising and Sales expenses, expenses on Research and Development expenses and Profit Margin .The figures are taken from the annual records of the Company which shows that as years are passing by ,the Company is making more and more profit leading to the growth and prosperity in the Company. Net Sales of the Company is growing year after year (Fig -3) along with the growth of capital employed. But if the growth of sales had been result of capital employed only, the sales/capital employed ratio would have been same over the period .On contrary; the said ratio is increasing year after year Table 2 that indicates the impact of other independent variables on the dependent variable sales or profit margin. So inter alia, we have taken into consideration the variables like Advertisement and Sales promotion and Research and Development expenses .These two expenses are increasing over time (Fig 3 and 6) and both have the impact on the growth of sales and profit margin. But it is crystal clear from Table 1 that the impact of Advertising and promotional expenses is more significant in companies to that of Capital employed or Research and Development expenses.

The model chosen for the analysis is the Regression analysis shown in (Table 3).It almost proves to be $96.4 \%$ significant .It explains the dependent variables on the Independent variables. The Anova table for the Hindustan Unilever Limited Company shows the F value to be more (i.e 22.194) the level is $>0.001$. Hence the ANOVAs value helps us to interpret that the variables taken in the analysis are significant.

The entire analysis shows that the variables taken are positively reacting and increasing the growth of sales of the company. The variables taken here are Capital Employed, Research and Promotional Expenses and Advertisement Expenses. It clearly shows that at least in FMCG sector the Advertisement Expenses are increasing the sales of this sector. The alternative hypothesis is therefore justified by the help of this case study of Hindustan Unilever Limited Company. The Multiple Regression analysis helps us to interpret that Advertisement Expenses is the only independent variable which is affecting the gross sales in a significant way as its $\mathrm{t}$ value is more than 2 (i.e. 20.214) at significance level 0.078. Capital Employed Expenses is not the independent variable which is affecting the gross sales in a significant way as its $t$ value is less than 2 (i.e. 0.079) at significance level 0.094. Research and Promotional Expenses is independent variable which is affecting the gross sales in a significant way as its t value is more than 2 (i.e. 10.681) at significance level 0.154. Though the Research and promotional expenses significance value is there but still in comparison of Advertisement expenses the $\mathrm{T}$-value is not as significant as in case of advertisement expenses by the Company. The other dependent variables are containing $t$ value more than 2 but they are insignificant in the model because of high P-value.

\section{Suggestions}

On the basis of findings of the research suggestions is given:

1. Customers' awareness regarding advertising is very high. Companies should take steps to maintain it.

2. Media are liked by customers due to their positive features. More media should be used to make consumers aware about it.

3. Tough competition is being faced by companies in market media planners should be more careful in giving message to the customers.

4. Media planners are playing important role major areas of advertising. The top level management should take care of them to satisfy, motivate and retain them in the current job.

5. Media selection factors are proper and these should be focused more carefully by media planners. Proper selection of media would give satisfactory results.

\section{Conclusions}

Since the FMCG sector is expected to grow several folds in the coming years, advertising in this sector will prove to be fruitful for any company. Sales are the lifeblood of any business. Without sales there would be no business. Therefore it is very important that if a business wants to succeed, it should have good sales. Advertising helps in increasing the sales of any product. It is important to study the consumer behavior and their choices especially in FMCG industry. The sector which could make the industry cheer the most would be FMCG. With the affluent and semi urban Indian waking up to the consumption of personal care, packed foods and beverage products, the cluttered FMCG market is likely to enhance its spends on advertising market's Srinivasan, FMCG Analyst, Angel broking said, "There would be a probable increase in ad spends in the FMCG sector, but one should not expect a drastic increase. It would depend on the demand. Demand looks positive and if the scenario remains such, spends would definitely increase. In fact, the players would focus more on positioning rather than marketing of product.

It is clear from the 2003-2004 to 2011-2012 year records that the sales of Hindustan Unilever Limited Company are dependent on the advertisement campaigning the Company is doing .The Company is expending 
more on the Research and Development which is actually helping them in innovating more. However the ratios, Multiple Regression, Pie Chart and various records from the Annual Reports have helped us to come to a conclusion that the growth of the select Company is dependent on Advertisement Expenses. In FMCG sector particularly where everyday newer and newer brands are coming in. No one perhaps will be able to retain the customers without Advertising. R \& D expenses are necessary, otherwise new brand cannot be launched, but without Advertising no new launch can be economically viable.

\section{References}

[1] Boyd, Harper W. Junior, Westfall, Ralph and Stasch, Marketing Research Text and Cases, Richard D. Irwin Inc, Homewood, Illinois.

[2] Russell, J. T., \& Lane, W. R. (1996).Advertising procedure USA: Prentice Hall Inc

[3] Kotler, Keller (2008), Framework for Marketing Management, Pearson Pub, New Delhi.

[4] Kotler Philip (2006), Framework for Marketing Management, Pearson Pub, New Delhi.

[5] Ogilvy, David (1983) Ogilvy on Advertising. New York: Crown Publishers.

[6] Hepner Harry Walker (1956). Modern Advertising: Practices and Principles McGraw-Hill,

[7] Sherlekar S.A (2007), marketing Management, Himalaya Pub, Mumbai.

[8] Jefkins Frank (1983) Advertising Made Simple, Publication: London heinemann

[9] Eachambadi, Naras V. (1994), "Does Advertising Work?" The McKinsey Quarterly (2), 117-129.

[10] Ayanwale, A. B., Alimi, T. \& Ayanbimipe, M. A. (2005). The Influence of Advertising on Consumer Brand Preference. Journal of Social Science, 10(1), 9-16.

[11] Wells, W., Burnett, J. \& Moriarty, S. (2000). “Advertising: Principles and Practice”. UpperSaddle River, New Jersey: Prentice-Hall

Hindustan Unilever Annual Reports (2003-2012).

Nielsen's quarterly Global AdView Pulse report.

International Research Journal of Finance and Economics - Issue 42 (2010) 97.

Kothari C.R (2009), Research Methodology: Methods \& Techniques, New Delhi.

Malhotra Naresh K (2007), Marketing Research: Applied Orientation, Pearson Pub, New Delhi.

Ramaswamy, Namakumari. (2007). Marketing Management: planning, Implementation \& Control. New Delhi:

Macmillan. 